\title{
Peranan Konseling Pastoral dalam Gereja bagi Pemulihan Kesehatan Rohani Jemaat
}

\author{
Samuel Irwan Santoso \\ Sekolah Tinggi Teologi Anugrah Indonesia \\ kelirbontang@gmail.com
}

\begin{abstract}
This study specifically outlines the role of pastoral counseling in the church for the restoration of the spiritual health of the church. This paper uses qualitative methods with a literature study approach. The description in this article describes that the interpersonal relationships between counselors and their consensual. Counseling comes from the Latin "Consillium" which means with or with and taking or holding. Pastoral counseling serves to heal the whole human being therefore pastoral counseling to help the "wounded", to survive and go through a state in which the recovery to the original condition. In applying pastoral counseling to the conggregation a counselor must understand how he or she should deal with the consequences. This is so that the counselor does not rush to blame or confront a person sharply and directly in the early stages of counseling. A good Christian pastor or counselor should put his or her function first rather than his office, for without real realization of the duty of responsibility one cannot be said to be a good shepherd or counselor.
\end{abstract}

Keywords: church; congregation; counseling; spiritual recovery

\begin{abstract}
Abstrak: Kajian ini secara spesifik menguraikan mengenai peran konseling pastoral dalam gereja bagi pemulihan kesehatan rohani jemaat. Tulisan ini menggunakan metode kualitatif dengan pendekatan studi kepustakaan. Uraian pada artikel ini menjelaskan bahwa hubungan timbal balik (interpersonal relationship) antara konselor dengan konselenya. Konseling berasal dari bahasa Latin "Consillium" yang berarti dengan atau bersama dan mengambil atau memegang. Pastoral konseling berfungsi untuk menyembuhkan manusia seutuhnya karena fungsi konseling pastoral untuk menolong orang yang "terluka", agar bertahan dan melewati suatu keadaan yang di dalamnya pemulihan kepada kondisi semula. Di dalam menerapkan konseling pastoral kepada jemaat seorang konselor harus memahami bagaimana seharusnya ia menghadapi konselinya. Ini bertujuan agar konselor tidak terburu-buru mempersalahkan atau mengkonfrontasi dengan tajam seseorang pada tahap permulaan konseling. Seorang gembala atau konselor Kristen yang baik harusnya lebih mengutamakan fungsinya daripada jabatannya, karena tanpa realisasi nyata dari tugas tanggung jawab yang diembannya seseorang tidak dapat dikatakan sebagai gembala atau konselor yang baik.
\end{abstract}

Kata kunci: gereja; jemaat; konseling; pemulihan rohani

\section{PENDAHULUAN}

Manusia adalah makhluk yang Tuhan ciptakan pada hari keenam. Dalam Kejadian 1:31 dicatat bahwa setelah Allah menciptakan manusia, Allah menilai itu semua amat baik. Penciptaan memberikan kepada manusia tempat mulia dalam alam semesta. Mulia menunjukkan penyataan diri, sifat dan kehadiran Allah kepada manusia. Ichwei G. Indra mengatakan: Manusia pada hakikatnya diciptakan menu- 
rut "gambar dan rupa Allah" (Kej. 1:26-27). Hal ini memberikan arti bahwa manusia memiliki kesamaan dengan Allah. Dengan demikian, Ichwei G. Indra mengatakan bahwa: Makna "gambar dan rupa Allah" di dalam diri manusia adalah: (1) kemampuan manusia untuk bersekutu dengan Allah (Kej. 1:28; 2:16-19); (2) kemampuan manusia untuk memahami dan melaksanakan kehendak Allah dalam penciptaan (Kej. 1:28). ${ }^{1}$

Manusia ditempatkan Tuhan di taman Eden. Semua keperluan jasmani manusia dipenuhi oleh Tuhan (Kej. 2:9). Tuhan Allah hanya memberikan satu peraturan yang membatasi kebebasan kuasa manusia untuk mengatur hidupnya, yaitu: "tetapi pohon pengetahuan tentang yang baik dan yang jahat, jangan kau makan buahnya, sebab pada hari engkau memakannya, pastilah engkau mati" (Kej. 2:17). Namun manusia itupun tergoda memakan buah tersebut, sehingga mereka harus merasakan hukuman dari Allah. Ketika pertama kali manusia jatuh ke dalam dosa, maka tindakan pertama Allah adalah mencari dan memanggil manusia yang bersembunyi dari hadapan Tuhan (Kej.2:8-9). Allah tahu bahwa manusia yang diciptanya itu telah melanggar aturan yang sudah ditetapkan oleh Allah. Tetapi Allah tidak membiarkan ciptaan-Nya itu larut dalam dosa karena Allah 'sadar' bahwa setiap orang membutuhkan pemeliharaan dan perawatan yang semakin besar ketika melalui masa sulit. ${ }^{2}$

Tindakan Allah mencari manusia mengidentifikasikan bahwa Allah adalah pelopor penggembalaan dan Tuhan sendiri sebagai gembala. Hal inilah yang disadari oleh Daud dalam kehidupannya yang penuh tantangan. Tuhan sebagai gembala yang baik bagi Daud menyediakan yang terbaik baginya baik dari segi jasmani maupun spiritual. Dari segi jasmani "Ia membaringkan aku di padang yang berumput hijau, Ia membimbing aku ke air yang tenang", dari segi spiritual "Ia menyegarkan jiwaku". Pemeliharaan Allah sebagai gembala yang baik menyegarkan jiwa yang tertekan karena dosa dengan pengampunan-Nya sekalipun dosa itu harus mendapat konsekuensi, namun sebelumnya Allah membina orang yang melakukan dosa kepada kebenaran. ${ }^{3}$

Dalam kitab Kejadian, dosa mempengaruhi hubungan nenek moyang pertama dengan Allah, mempengaruhi sifat mereka, mempengaruhi tubuh mereka dan alam di sekitar mereka. Sebelum kejatuhan manusia, Allah dan manusia bersekutu satu sama lain; setelah kejatuhan, persekutuan itu putus. Mereka bukannya mencari persekutuan dengan Allah malah berusaha lari menjauhi Allah. Hati nurani mereka yang merasa tertuduh membuat mereka tidak dapat merasa tenang, sehingga mereka mulai berusaha mengalihkan tanggungjawab. Pelanggaran yang Adam dan Hawa lakukan membuat mereka malu (Kej.3:7).

\footnotetext{
${ }^{1}$ Ichwei G Indra, “Allah—Manusia Sejati” (Semarang: Pelayanan Kristen Mandiri Mikhael, 2000)

${ }^{2}$ Jonar T H Situmorang, Soteriologi: Doktrin Keselamatan, Pengajaran Mengenai Karya Allah Dalam Keselamatan (PBMR ANDI, 2021).

${ }^{3}$ Waharman Waharman, "Prinsip Penggembalaan Dalam Mazmur 23," Manna Rafflesia 1, no. 2 (2015): 93-111.
} 
Dalam Perjanjian Baru Tuhan Yesus juga melakukan pelayanan penggembalaan. Dalam Yohanes 4:1-26, Yesus melayani seorang perempuan Samaria yang hidup dalam perzinahan. Perempuan Samaria tersebut secara sosial terkucilkan dalam lingkungan masyarakatnya, serta dijauhi masyarakat setempat. Secara mental pasti ia juga merasa rendah diri dan merasa diri tidak layak bahkan ia tidak berani bergabung atau berkumpul dengan orang-orang yang ada di sekitarnya. Namun Tuhan Yesus justru datang dan duduk bersama perempuan samaria tersebut serta membuat ia merasa berharga, padahal ia menyadari bahwa sesungguhnya ia manusia yang sangat berdosa. ${ }^{4}$ Walaupun Yesus mengasihi dan mendekati orang berdosa, Ia tidak tutup mata terhadap kesalahan yang mereka lakukan. Yesus mengasihi orang-orang berdosa, tetapi Ia membenci dosa. Begitulah seharusnya pergaulan gembala dengan orang yang melakukan pelanggaran. Justru yang berbuat salah yang harus didekati, dikunjungi, karena orang yang sakit memerlukan dokter lebih daripada yang sehat. ${ }^{5}$

Orang yang melakukan pelanggaran yang perlu didekati, ditolong dan digembalakan, tetapi tidak berarti bahwa gembala juga membenarkan perbuatan atau perkataan jahat orang yang berbuat salah, akan tetapi membawa mereka kepada pertobatan dan hidup yang baru. ${ }^{6}$ Tidak senang dengan diri sendiri, sebagaimana diri sendiri adanya, dan karena itu tidak senang kalau dilihat orang lain. Ketika Allah mengatakan dalam Kejadian 2:17 bahwa akibat ketidaktaatan manusia adalah "pasti akan mati". Allah berfirman kepada Adam, "Sebab engkau debu dan engkau akan kembali menjadi debu" (Kej. 3:19). Kata-kata Paulus, "sama seperti semua orang mati dalam persekutuan dengan Adam (1 Kor. 15:22), terutama menunjuk kepada kematian jasmaniah.

Fakta menunjukkan berbagai problematika dialami oleh jemaat yang berdampak pada kesehatan rohani rohani merka. Penyebab terganggunya kesehatan rohani jemaat datang dari permasalahan rumah tanggga, perceraian, narkoba, terjerat hutang piutang, dirundung sakit penyakit da kedukaan, salah pergaulan dan sebagainya. Riak-riak problematika yang dialami oleh jemaat menyebabkan kerohanian umat perlu pemulihan. Agar pemulihan kerohanian tercipta, konseling dapat menjadi wadah yang digunakan oleh gembala untuk menjembatani dalam pelayanan pastoral. Alkitab secara luas mendeskripsikan prinsip-prinsip penggembalaan yang Allah lakukan yaitu mencari yang hilang, membawa pulang yang tersesat, membalut yang luka, menguatkan yang sakit serta melindungi yang gemuk dan yang kuat. Hal yang serupa harusnya dilakukan oleh gereja atau gembalagembala zaman sekarang. Orang-orang yang mengalami keterpurukan membu-

\footnotetext{
${ }^{4}$ Karnawati Karnawati, Nanda Christiani Ayudea Yahya, and I Putu Ayub Darmawan, “Tahapan Pembelajaran Yesus Pada Perempuan Samaria," Davar: Jurnal Teologi 1, no. 1 (2020): 9-18.

${ }^{5}$ Harming Harming, "Metode Penginjilan Yesus Dalam Injil Yohanes 4: 1-42," Evangelikal 1, no. 2 (2017): 162-169.

${ }^{6}$ Lena Anjarsari Sembiring \& Simon Simon, "Rumah Tangga Gembala Sidang Menjadi Role Model Bagi Jemaat," Teologi Praktika 1, no. 2 (2020).
} 
tuhkan gereja dan gembala-gembala yang perduli, yang memperhatikan serta membina mereka agar tidak larut dalam keterpurukan tersebut. ${ }^{7}$

Berdasarkan tujuan penelitian yang hendak dicapai, maka penelitian ini diharapkan mempunyai manfaat dalam pendidikan baik secara langsung maupun tidak langsung. Adapun manfaat penelitian ini secara teoritis hasil penelitian ini diharapkan dapa bermanfaat sebagai sumbangan ilmiah dalam ilmu bidang pelayanan praktis, yaitu memberikan paradigma baru tentang panggilan dalam pelayanan. Sementara secara praktis penelitian ini dapat bermanfaat bagi pelayan Tuhan dengan memperoleh referensi bagaimana seharusnya melayani sebagai konselor yang baik.

\section{METODE PENELITIAN}

Adapun jenis penelitian yang digunakan peneliti ini adalah penelitian kepustakaan. Subagyo menjelaskan yang dimaksud penelitian kepustakaan sebagai berikut: Penelitian yang menjadikan data-data kepustakaan sebagai teori untuk dikaji dan ditelaah dalam memperoleh hipotesa atau konsepsi untuk mendapatkan hasil yang objektif. Dengan jenis ini informasi dapat diambil secara lengkap untuk menentukan tindakan ilmiah dalam penelitian sebagai instrumen penelitian memenuhi standar penunjang penelitian. ${ }^{8}$ Dengan demikian, dalam penyusunan karya ilmiah ini penulis menentukan topik yang akan dibahas yang kemudian dilanjutkan dengan mencari data-data baik itu yang relevan ataupun mendukung terhadap topik yang dibahas. Setelah mendapatkan data, penulis melakukan interpretasi atau penafsiran terhadap sumber data untuk memperoleh fakta tentang kajian yang akan dibahas. Setelah terkumpul maka data disusun secara sistematis dan terstruktur.

\section{HASIL DAN PEMBAHASAN}

\section{Pengertian Konseling Pastoral}

Dalam memahami pengertian "konseling pastoral", terlebih dahulu kita melihat pengertian secara etimologis dari kedua kata tersebut, yakni pastoral dan konseling. Menurut Aart van Beek, istilah pastoral berasal dari "pastor" dalam bahasa Latin atau dalam bahasa Yunani disebut "Poimen" yang artinya "gembala". Istilah pastor dalam konotasi praktisnya berarti merawat atau memlihara. Pengistilahan ini dihubungkan dengan diri Yesus dan karya-Nya sebagai "Pastor sejati" atau "Gembala yang baik" (Yoh. 10). Ungkapan ini mengacu pada pelayanan Yesus tanpa pamrih, bersedia memberikan pertolongan dan pengasuhan terhadap pengikut-Nya, bahkan rela mengorbankan nyawa-Nya. Pelayanan yang diberikan-Nya ini merupakan tugas manusiawi yang teramat mulia. Para pengikut-Nya diharapkan dapat mengambil sikap dan pelayanan Yesus ini dalam kehidupan praktis mereka. Oleh karena itu, tugas Pastoral bukan hanya tugas resmi atau monopoli para Pastor

\footnotetext{
${ }^{7}$ Simon Simon, "Peranan Gereja Dalam Menghambat Laju Pertumbuhan Pemakai Narkoba," Jurnal Ilmiah Religiosity Entity Humanity (JIREH) 1, no. 2 (2019): 172-186.

${ }^{8}$ Joko Subagyo, “Metode Penelitian Dan Praktek," Jakarta: Rhineka Cipta (1991).
} 
atau Pendeta saja, tetapi juga setiap orang yang menjadi pengikut-Nya. ${ }^{9}$ Sedangkan istilah konseling berasal dari bahasa Latin "Consillium" yang berarti dengan atau bersama dan mengambil atau memegang. Konotasinya ada sesuatu yang harus dipegang, diambil bersama-sama. ${ }^{10}$

Menurut Oates, konseling adalah suatu disiplin ilmu non-medis yang sasarannya adalah untuk memberi fasilitas dan menimbulkan pertumbuhan serta perkembangan kepribadian, menolong pribadi-pribadi untuk mengubah pola-pola kehidupan yang menyebabkan mereka mengalami kehidupan yang makin tidak berbahagia, dan menyediakan suasana persaudaraan dan kebijaksanaan bagi pribadi-pribadi yang sedang menghadapi kehilangan dan kekecewaan dalam kehidupan yang tidak dapat dihindari. ${ }^{11}$ Istilah konseling dalam Perjanjian Lama, misalnya dalam I Tawarikh 27:32 "soferim" yang diterjemahkan dalam bahasa Inggris counselor, artinya "penasihat". Istilah ini juga muncul dalam Yesaya 9:6 "misera" (counselor), sehubungan dengan kedatangan Yesus sebagai Penasehat Ajaib. Dalam Perjanjian Baru, istilah counselor paling sering muncul dalam hubungan dengan Roh Kudus (Yunani: parakletos) ; dalam bahasa Indonesia diterjemahkan sebagai penghibur, penasihat, penolong. ${ }^{12}$ Demikianlah dipahami bahwa istilah Konseling itu bukanlah suatu hal baru bagi kehidupan orang Kristen. Konseling dalam pengertian ini diartikan sebagai suatu tindakan yang dihubungkan dengan pekerjaan penghibur, penasihat dan penolong, di mana ada keterlibatan Roh Kudus.

Berdasarkan definisi di atas, nampak paling tidak ada empat aspek penting yang harus dikenal oleh setiap Konselor (hamba Tuhan), yaitu: (a) Hubungan timbal balik (interpersonal relationship) antara konselor dengan konselenya; (b) Hamba Tuhan sebagai Konselor; (c) Suasana percakapan konseling yang ideal (condusive atmosphere); (d) Melihat tujuan hidupnya dalam relasi dan tanggung jawabnya pada Tuhan dan mencapai tujuan itu dengan takaran, kekuatan dan kemampuan seperti yang sudah diberikan Tuhan padanya.

\section{Fungsi Konseling Pastoral}

Dalam sepanjang periodisasi pastoral, pelayanan pastoral itu sangat dipengaruhi oleh keadaan dan situasi serta kebutuhan individu sebagai konseli pada saat itu. Demikian halnya, dengan keempat fungsi pastoral, yakni menyembuhkan, menopang, membimbing dan memperbaiki hubungan, telah mengalami perkembangan dan perubahan baik mengenai defenisinya, tujuan maupun metode dari keempat fungsi ini dalam pelayanan pastoral. Berkaitan dengan fungsi Pastoral dalam sejarah gereja dan pelayanan pastoral, William A. Clebsch dan Charles R.

\footnotetext{
${ }^{9}$ Aart van Bee, Pendampingan Pastoral (Jakarta: BPK Gunung Mulia, 2007), bk. 10.

${ }^{10}$ Ibid.

${ }^{11}$ Wayne E Oates, Pastoral Counseling (Westminster John Knox Press, 1981), bk. 9.

${ }^{12}$ E. P. Gintings, Gembala \& Konseling Pastoral (Yogyakarta: ANDI, 2002), bk. 2.
} 
Jackle menguraikan empat fungsi pastoral, yang secara ringkas seperti berikut ini: ${ }^{13}$ Pertama, penyembuhan. fungsi pastoral yang bertujuan untuk mengatasi beberapa penurunan nilai dan memulihkan seseorang kepada keutuhan dengan cara menuntun dia untuk terus maju dan melalui kondisi sebelumnya. Pastoral konseling berfungsi untuk menyembuhkan manusia seutuhnya. Menurut kesaksian Alkitab, manusia adalah manusia yang utuh, yang terdiri dari tubuh dan jiwa. Keutuhan manusia juga terjadi ketika hidup bersama dengan orang lain, menjalin hubungan atau relasi dalam suatu konteks politik, sosial dan suatu kebudayaan tertentu. Dalam hal pendampingan pastoral, fungsi menyembuhkan ini penting dalam arti bahwa melalui pendampingan yang berisi kasih sayang, rela mendengarkan segala keluhan batin, dan kepedulian yang tinggi akan membuat seseorang yang sedang tertekan mengalami rasa aman dan kelegaan sebagai pintu masuk ke arah penyembuhan yang sebenarnya. Selain relasi dengan sesama terpulihkan, manusia terlebih harus mengutamakan relasinya dengan Tuhan mengalami pemulihan. Menyembuhkan manusia seutuhnya berbicara mengenai pemulihan manusia secara totalitas dan hal ini membutuhkan proses yang panjang untuk dilakukan seorang konselor. ${ }^{14}$

Kedua, penopangan. Fungsi pastoral untuk menolong orang yang "terluka" untuk bertahan dan melewati suatu keadaan yang di dalamnya pemulihan kepada kondisi semula atau kemungkinan penyembuhan dari penyakitnya itu adalah sangat tipis. Seringkali konselor diperhadapkan kepada seseorang yang tiba-tiba mengalami krisis mendalam dan seringkali juga pada saat itu konselor tidak dapat berbuat banyak untuk menolong. Keadaan ini bukan berarti konselor tidak dapat melakukan pendampingan.Tetapi kehadiran konselor adalah untuk membantu seseorang bertahan dalam situasi krisis berat. Sokongan berupa kehadiran dan sapaan yang meneduhkan dan sikap terbuka akan mengurangi penderitaan seseorang. Jadi kehadiran seorang konselor sangat berarti bagi setiap konseli untuk dapat memberi dukungan berupa motivasi bagi konseli agar konseli dapat bangkit dari keterpurukan yang sedang dialami. ${ }^{15}$ Ketiga, membimbing. Fungsi pastoral untuk penyembuhan jiwa, yang berkaitan dengan pertolongan bagi orang yang mengalami kebingungan dalam pengambilan keputusan tertentu atas berbagai pilihan sulit yang dimilikinya. Pelayanan pastoral atau pengembalaan adalah suatu proses yang panjang. Proses ini dapat kita umpamakan dengan suatu jalan yang harus ditempuh oleh konseli yang kita layani. Oleh karena itu konseli tidak dapat menempuhnya seorang diri, ia membutuhkan orang lain atau konselor yang dapat menuntun dan membimbingnya.

Keempat, rekonsiliasi. Fungsi pastoral untuk membantu orang yang sedang terasing untuk membangun atau memperbaharui hubungan yang tepat dan berbuah

\footnotetext{
${ }^{13}$ William A Clebsch and Charles R Jaekle, Pastoral Care in Historical Perspective (Jason Aronson, Incorporated, 1994), bks. 33-66.

${ }^{14}$ Yenny Anita Pattinama, "Pastoral Konseling Menurut Yehezkiel 34: 16 Sebagai Upaya Pemulihan Mental," SCRIPTA: Jurnal Teologi dan Pelayanan Kontekstual 6, no. 2 (2018): 172-183.

${ }^{15}$ Ibid.
} 
dengan Allah dan sesama. Dalam pelayanan pastoral kita sering bertemu dengan orang-orang yang hidup terpisah atau terasing, baik dari orang-orang yang ada disekitarnya, maupun persekutuan mereka dengan Allah. Menurut pendapat para ahli fungsi mendamaikan ialah, berusaha memperbaiki relasi yang rusak antara manusia dan sesamanya manusia, serta manusia dengan Allah. Jadi pastoral konseling juga berfungsi untuk menolong dan mendamaikan serta memperbaiki hubungan manusia dengan sesama, maupun hubungannya dengan Tuhan. ${ }^{16}$

Seiring dengan perkembangan waktu dan sesuai dengan perkembangan pemikiran para tokoh pastoral, kebutuhan dan persoalan yang dialami manusia, maka keempat fungsi pastoral di atas mengalami penambahan jumlah, antara lain seperti menurut Clinebell dalam bukunya Tipe- Tipe Dasar Pendampingan dan Konseling Pastoral, menambahkan fungsi kelima dari Konseling Pastoral, yaitu memelihara atau mengasuh (nurturing). Tujuan dari memelihara adalah memampukan orang untuk mengembangkan potensi-potensi yang diberikan Allah kepada mereka, di sepanjang perjalanan hidup mereka dengan segala lembah-lembah, puncak-puncak dan dataran-datarannya. Dalam fungsi ini, dapat menggunakan beberapa cara seperti latihan bagi anggota-anggota baru dalam hidup Kristiani, pendidikan agama yang didapat diterapkan dalam pelaksanaan konseling edukatif, kelompok pertumbuhan perkawinan dan keluargga, dan sebagainya. ${ }^{17}$ Sehubungan dengan fungsi ini, Aart van Beek juga menambahkan pemahamannya bahwa dalam penerapan fungsi ini diharapkan konseli akan berkembang dan terus menerus menjadi dewasa di dalam menghadapi masalah-masalah hidup. ${ }^{18}$

\section{Proses Konseling}

Dalam melakukan proses konseling, seorang konselor harus memahami bagaimana seharusnya ia menghadapi konselinya. Ada dua aspek utama yang akan dihadapi oleh konselor yakni aspek emosi dan aspek perilaku dari konseli di mana perlu perhatian yang seimbang antara keduanya. Konselor mengizinkan konseli mengungkapakan perasaan/emosi yang bergejolak secara bebas dan jujur dan kemudian menuntun konseli untuk mengevaluasi perilakunya, dan di dalamnya mengakui secara jujur akan perilaku yang menyimpang atau yang tidak sesuai dengan standar kebenaran Firman Tuhan. Hal ini senada dengan pernyataan Meier bahwa konseling Kristen harus menyentuh kedua aspek tersebut demi penanganan yang tepat dan menyeluruh. ${ }^{19}$ Ia menjelaskan perlunya prinisip keseimbangan tersebut. Konseli perlu diberi kesempatan untuk menyalurkan perasaannya. Hal ini membantu mereka mengatasi kemarahan yang dipendam yang menyebabkan depresi dan membantu membawa kekhawatiran itu dari tingkat bawah sadar ke tingkat sadar, di mana

\footnotetext{
16 Ibid.

${ }^{17}$ Howard John Clinebell, Tipe Tipe Dasar Pendampingan |\& Konseling Pastoral (Kanisius,

${ }^{18}$ Aart van Bee, Pendampingan Pastoral, bk. 12.

${ }^{19}$ Paul Meier et al., "Pengantar Psikologi Dan Konseling Kristen," Yogyakarta: PBMR ANDI
} 2002), bk. 54. (2004): 189. 
hal itu bisa ditangani dengan tepat. Namun konselor Kristen harus bergerak lebih jauh dari sekedar memberi perhatian pada perasaan untuk menangani perilaku.

Hal ini memperingatkan konselor agar tidak terburu-buru mempersalahkan atau mengkonfrontasi dengan tajam seseorang pada tahap permulaan konseling, tetapi juga tidak hanya terfokus pada masalah 'perasaan' tetapi harus meningkat pada masalah 'perilaku. Adapun hal pertama, yakni menaruh perhatian terhadap aspek emosi yaitu pengakuan yang jujur akan perasaan atau emosi yang berkaitan dengan satu perisitwa tertentu dan mengakui dosa spesifik merupakan ajaran yang ditekankan Alkitab dalam hubungannya dengan kesehatan kehidupan rohani maupun emosi seseorang. Mengenai pengakuan jujur akan emosi yang terkandung dalam sebuah perisitiwa tertentu.

Contoh lainnya, Ayub memilih menyalurkan emosinya lewat keluh kesahnya di hadapan Tuhan (Ayb. 7:2). Prinsip kejujuran ini penting agar supaya emosi negatif yang dialami seseorang tidak menjadi seperti "bumerang" bagi dirinya sendiri dengan merusak fisik dan tidak menjadi racun yang mematikan bagi hubungan dengan sesama terkhususnya dengan Tuhan sendiri. ${ }^{20}$ Philip Yancey dalam buku Kitab Suci yang Dibaca Yesus menyebut pengakuan yang jujur ini sebagai terapi jiwa yang tertekan yang menyehatkan karena dapat membawa perasaan apa saja kepada Tuhan, beserta kelemahan-kelemahan di mana hanya Tuhan satu-satunya yang memiliki kuasa untuk menyembuhkannya. ${ }^{21}$ Faktanya, banyak orang tidak terbiasa mengakui perasaanya secara jujur di hadapan Tuhan dan tetap tinggal dalam pengakuan yang kaku dan umum.

Menyembunyikan aspek-aspek tentang diri kita menyebabkan aspek-aspek itu masuk dalam kegelapan dan mengambil kehidupan mereka sendiri. Seluruh rombongan besar kebencian dan dukacita tertutupi (di dalam kata-kata Yesus). ${ }^{22}$ Akibat dari sikap seperti ini, adalah jusrtu menambah berat beban mental seseorang. Selanjutnya mengenai aspek perilaku. Berhubungan dengan hal ini, konseli perlu mengakui jika sekiranya terdapat penyimpangan terhadap standar kebenaran dalam Firman Tuhan yang telah dilakukannya. Dalam persepektif Kristen, segala sesuatu yang dilakukan bertentangan dengan Firman Tuhan adalah dosa. Konseli perlu mengakui dosanya dan pengakuan itu seharusnya menjadi pengakuan secara spesifik. Pentingnya pengakuan dosa secara spesifik ini disampaikan jelas dalam 1 Yohanes 1:9. Kata a 'marti,aj (hamartias) dalam ayat ini didahului oleh definit artikel "ta.j" (tas). Definitif artikel, atau pembatas obyek biasanya diterjemahkan "itu". Ide dari pemakaian artikel ini adalah bahwa hal yang disebut dibatasi atau spesifik "yang itu". Ini berarti pengakuan dosa yang dimaksud adalah dosa-dosa yang ditunjuk dan dijelaskan secara spesifik kepada Tuhan, "dosa yang itu.

\footnotetext{
${ }^{20}$ Sherly E.E Kawengian, "Tinjauan Teologis Terhadap Emosi Negatif Daud Dalam Mazmur 54:1-14 Dan Implikasinya Bagi Orang Percaya Dalam Situasi Sukar” (Sekolah Tinggi Teologia Injili Indonesia, 2004), bk. 121.

${ }^{21}$ Yancey Philip, Kitab Suci Yang Dibaca Yesus (Batam: Interaksara, 2001), bks. 121-123.

${ }^{22}$ Henry Cloud, Changes That Heal: How to Understand Your Past to Ensure a Healthier Future (Zondervan, 1996), bk. 239.
} 


\section{Landasan Teologis Pelaksanaan Konseling Pastoral Mandat Ilahi dari Tuhan}

Untuk memahami betapa pentingnya pelayanan konseling pastoral perlu diperhatikan terlebih dahulu kesaksian Alkitab. Sesuai dengan kesaksian Alkitab, baik Perjanjian Lama maupun Perjanjian Baru bahwa pendampingan (konseling) itu bersumber dari Allah sendiri. Di dalam Kejadian 3, misi pendampingan itu dilakukan oleh Allah sendiri. Allah hadir di saat Adam (manusia) berada dalam keterasingan, kesepian, ketakutan dan kecemasan serta perasaan malu karena perbuatannya. Allah hadir dalam suatu relasi khusus untuk mendampingi, menopang dan membimbingnya, sehingga ia dapat hidup secara bertanggung jawab atas segala perbuatannya. Dalam pendampingan itu Allah mendamaikan dan memulihkan hubungannya yang telah terputus dengan Allah maupun dengan lingkungannya, sehingga relasi itu dapat tercipta kembali secara baru yang penuh makna. Dalam pendampingan itu juga Allah mengadakan atau mengikat Perjanjian dengan Adam (Kej. 3:15), dan selanjutnya Allah dan manusia itu bertemu dan saling berhubungan dalam ikatan relasi Perjanjian."23

Selanjutnya, pendampingan itu Allah nyatakan kepada umat manusia dalam berbagai cara. Dalam kitab Kejadian 12 misalnya, Allah mengambil inisiatif untuk menjumpai Abram dalam situasi kehidupannya. Allah membimbing dan mempersiapkannya melalui panggilan itu supaya olehnya seluruh dunia beroleh berkat (Kej. 12: 3). Dengan kata lain Allah mendampingi Abram untuk mempersiapkannya menjadi sarana kasih karunia Allah bagi sesamanya. Melalui pendampingan itu Abram dilengkapi untuk mengambil peran dan tanggung jawab sebagai orang percaya. Pendampingan itu tidak berhenti dengan Abram, melainkan terus berlanjut dengan pemilihan dan pembebasan bangsa Israel. ${ }^{24}$ Pembebasan ini terjadi ketika umat Allah berada dalam kesulitan, perbudakkan dan penindasan. Di dalam kondisi yang memprihatinkan itulah Allah hadir di tengah-tengah mereka, untuk mendampingi dan membebaskan mereka. Melalui pembebasan itulah mereka dapat berfungsi secara utuh dan penuh sebagai umat pilihan Allah. Melalui pembebasan itu Allah kembali membaharui ikatan Perjanjian-Nya dengan umat Israel. Hubungan antara Allah dengan Israel dipererat dan relasi tersebut tercipta oleh karena tindakan Allah sendiri. Oleh karena Allah rela mendampingi mereka, maka mereka beroleh pembebasan. Dengan demikian mereka dapat mewujudkan dirinya dalam karya yang baru, dalam relasi yang baru pula dengan Allah maupun dengan sesamanya. ${ }^{25}$

\footnotetext{
23 Tjaard Band \& Anne Hommes, Konseling Krisis (Yogyakarta: Pusat Pastoral, 2000), bk. 409.

${ }^{24}$ Simon Simon and Alvonce Poluan, "Model Kepemimpinan Yang Ideal Dalam Penataan Organisasi Gereja," SHAMAYIM: Jurnal Teologi dan Pendidikan Kristiani 1, no. 2 (2021): 133-147. ${ }^{25}$ Johannes Ludwig Chrysostomus Abineno, Aku Percaya Kepada Allah (BPK Gunung Mulia, 1983), bks. 39-41.
} 
Pada jaman para nabi, Allah selalu digambarkan sebagai Gembala bagi umatNya (Yes. 40 : 11; Yehe. 34; dan Mazmur 23). Gambaran bahwa Allah sebagai Gembala bagi umat-Nya menunjuk kepada suatu hubungan pemeliharaan yang dinamis oleh Allah. Hal ini menunjuk pula kepada fungsi penggembalaan seperti yang dikemukakan oleh Clinebell yaitu: penyembuhan; penopangan; pembimbingan; pendamaian; dan pemeliharaan. ${ }^{26}$ Allah selaku Gembala bagi umatNya, selalu menghantar domba-dombanya dan membaringkannya di padang yang berumput hijau. Ia selalu memimpin ke air tenang yang menyegarkan jiwa, dan menuntun ke jalan yang benar serta mengaruniakan kebahagiaan seumur hidup (Mazmur 23).27

Gambaran ini akhirnya digenapi oleh Tuhan Yesus Kristus Sang gembala yang baik. Tuhan Yesus adalah satu-satunya Gembala yang baik (Yohanes 10), yang mengenal dan memanggil domba-domba-Nya menurut namanya masing-masing. Pengenalan secara mendalam ini terjadi berkat relasi pendampingan yang baik dan secara terus menerus. Kehadiran Tuhan Yesus di antara manusia, memungkinkan manusia beroleh kelimpahan dan hidup yang kekal. ${ }^{28}$ Setelah kebangkitan dan kenaikan Tuhan Yesus ke Sorga, Roh Kudus diutus oleh Allah Bapa atas nama Tuhan Yesus untuk menyertai dan mendampingi orang percaya. Roh Kudus adalah pendamping dan penghibur yang sejati yang datang dari Allah untuk mendampingi dan menghibur bahkan tinggal di dalam hati setiap orang percaya (Yoh. 14: 16 17) ${ }^{29}$. Jay Adams mengatakan Roh Kudus adalah seorang Konselor dan Ia mengatasi segala konselor. ${ }^{30}$ Pendampingan oleh Roh Kudus berlangsung sampai selamalamanya, yang terjelma di dalam kepedulian orang percaya terhadap sesamanya.

\section{Konseling Pastoral dan Pembinaan Jemaat}

Salah satu fungsi pastoral yang di kemukakan oleh Clinebell, adalah pembinaan. (nurturing). ${ }^{31}$ Pembinaan ini bermaksud agar individu yang telah beroleh pertolongan penyembuhan melalui konseling pastoral secara terus-menerus mengembangkan segala potensi yang di berikan Tuhan kepadanya. Dasar pemikiran teologis di sini adalah bahwa warga tersebut telah beroleh "penyucian dan penebusan" oleh kasih Allah dalam Yesus Kristus, tetapi ia harus terus bertumbuh di dalam kedewasaan penuh dalam kristus, namun di sadari pula bahwa individu yang telah mendapatkan "rahmat Allah" tersebut masih akan terus berhadapan dengan berbagai persoalan di sepanjang hidupnya, oleh karena itu fungsi pembinaan ini adalah sangat penting. Pembinaan di sini lebih menekankan pada bagaimana seseorang dibekali dan dimampukan agar ia dapat mengatasi akan persoalannya

\footnotetext{
${ }^{26}$ Howard John Clinebell and Bridget Clare McKeever, Basic Types of Pastoral Care |\& Counseling: Resources for the Ministry of Healing and Growth (Abingdon Press, 2011), bk. 43.

${ }^{27}$ Clinebell and McKeever, Basic Types of Pastoral Care |\& Counseling: Resources for the Ministry of Healing and Growth.

${ }^{28}$ J.L.Ch. Abineno, Ibid., 16.

${ }^{29}$ G.C. Van Niftrik dan B. J. Boland, Dogmatika Masa Kini, (Jakarta: BPK Gunung Mulia, 1984), 340.

${ }^{30}$ Ibid., 340.

${ }^{31}$ Tjaard Band \& Anne Hommes, Konseling Krisis.
} 
secara mandiri. Oleh karena itu pula maka pembinaan ini dapat meliputi berbagai hal seperti latihan dasar untuk menolong diri sendiri dalam menghadapi persoalan, latihan dasar untuk mengenal gejala gejala persoalan dll. Dengan singkat dapat dikatakan bahwa pembinaan itu meliputi aspek fisiknya, jiwanya dan rohaninya. ${ }^{32}$

Dalam masalah misalnya kekuatiran, tampak bahwa individu kurang percaya diri, kehilangan integritas dengan sesamanya sehingga kurang sekali terdapat kemungkinan baginya untuk ia dapat berbagi rasa. Apabila keadaan demikian berlanjut terus maka akan sangat melumpuhkan segala potensi di dalam dirinya. Tetapi gereja sebagai persekutuan dengan fungsi bimbingannya akan sangat memungkinkan bagi individu untuk dapat berbagi rasa dengan sesamanya dan sekaligus belajar untuk mengembangkan ketrampilan bergaul dengan sesamanya. ${ }^{33}$ Tampaknya hal inilah yang telah dilakukan oleh Tuhan Yesus, ketika Ia menyuruh orang yang telah sembuh untuk kembali kepada groupnya. Persekutuan yang dikehendaki oleh Tuhan Yesus adalah persekutuan baru di mana tiap anggota saling merasa ketergantungannya satu dengan yang lainnya. Segala macam isolasi harus dilepaskan dan masuk ke dalam persekutuan baru di dalam kebersamaan yang bersifat universal. Di dalam persekutuan yang demikian tiap tiap individu merasa memiliki sesuatu yang berharga yang perlu dibagikan di dalam pembinaan dan persekutuan. ${ }^{34}$

\section{Peran Alkitab dalam Konseling Pastoral}

Sebagaimana telah disinggung pada sebelumnya bahwa "pastoral" memberi tekanan dan arah yang berakar dalam berita injil. Tentu Alkitab sebagai sumber rohani mempunyai peran yang penting dalam konseling pastoral. Penggunaan Alkitab sebagai sumber rohani, bukanlah hal baru bagi para rohaniawan. Menurut Hiltner, Alkitab sebagai sumber rohani dapat dipergunakan dalam pelayanan konseling pastoral. Tetapi ia juga mengingatkan bahwa pemakaian Alkitab sebagai sumber rohani, hendaknya dilakukan dengan berhati-hati. Tidak semua masalah dapat dikategorikan dan ditangani sebagai masalah rohani. Alkitab sebagai sumber rohani dapat dipakai, jikalau inti permasalahan seseorang telah diketahui secara jelas. ${ }^{35}$ Penggunaan Alkitab dengan baik dan tepat akan menjadi sarana yang penuh kuasa untuk membina dan membangun keutuhan spiritual. ${ }^{36}$

Di samping itu Alkitab juga dapat bermanfaat untuk memberikan penghiburan dan kekuatan bagi seseorang yang tengah menghadapi berbagai krisis kehidupan. Bagian yang sangat terkenal secara luas adalah bagian-bagian dari kitab Mazmur,

\footnotetext{
${ }^{32}$ Simon and Poluan, "Model Kepemimpinan Yang Ideal Dalam Penataan Organisasi Gereja."

${ }^{33}$ Mikha Agus Widiyanto and S Susanto, "Pengaruh Pelayanan Kunjungan Pastoral Terhadap Pertumbuhan Rohani Jemaat," Evangelikal: Jurnal Teologi Injili Dan Pembinaan Warga Jemaat 4, no. 1 (2020): 39-46.

${ }^{34}$ Marthen Nainupu, “Konseling Pastoral Dalam Gereja: Res Sine Qua Non,” JTA 20, no. 11 (2009): 78-100.

${ }^{35}$ Donald Capps, Biblical Approaches to Pastoral Counseling (Wipf and Stock Publishers, 2003), bks. 19-20.

${ }^{36}$ Clinebell and McKeever, Basic Types of Pastoral Care |\& Counseling: Resources for the Ministry of Healing and Growth, bk. 122.
} 
misalnya Mazmur 38, seperti yang dikemukakan oleh Hiltner maupun Wise bahwa perasaan-perasaan yang terungkap dalam Mazmur ini adalah bagian dari perasaan umat manusia yang bergumul dengan segala permasalahan dan sakit penyakit. Sementara menurut Oates, bagian ini merupakan Mazmur penghiburan bagi manusia di dalam segala kesukaran hidupnya. ${ }^{37}$

Selanjutnya menurut Capps Alkitab dapat berfungsi sebagai alat untuk mendiagnosa masalah. Oates dalam The Bible in Pastoral Care, maupun Wise dalam Psychiatry and the Bible menjelaskan bahwa Alkitab dapat memberi petunjuk dan penerangan terhadap dinamika-dinamika batin dan masalah masalah seseorang, yang saling terkait dengan pokok-pokok dalam Alkitab. Tema-tema Alkitab seperti pemeliharaan, pertobatan, iman dan anugerah dapat menjadi bagian yang penting dan unik untuk menghantar seseorang menemukan pengertian teologis yang diperolehnya melalui proses dan bantuan layanan konseling. Memang disadari bahwa tidak semua masalah langsung berkaitan dengan masalah rohani, akan tetapi hampir sebagian besar masalah manusia mempunyai kaitan dengan sumber-sumber rohani, seperti yang diungkapkan oleh Link bahwa masalah utama dari klienkliennya bersumber pada kehilangan nilai-nilai, kehabisan kepercayaankepercayaan dan kehilangan sasaran kehidupan. Ungkapan Link ini sejalan dengan pengalaman kilinis dari Carl Gustav Jung yang mengatakan bahwa diantara semua pasien yang berusia di atas 35 tahun, pada akhir konsultasinya selalu menanyakan ulang tentang kepercayaan dan keagamaannya. ${ }^{38}$

\section{Konseling Pastoral dalam Gereja Sebagai Sarana Pemulihan Kesehatan Rohani Jemaat}

Kesehatan rohani adalah kehidupan kerohanian yang menunjukkan punya relasi dekat dengan Allah walau seseoorang itu mengalai berbagai probelmatika kehidupan. Kesehatan rohani juga dapat disebut konsistensi menjaga dan mempertahankan iman kepada Allah tanpa berkurang kesetiaan dalam menjalin hubungan yang semakin erat dengan Tuhan. Kesehatan rohani juga tidak hilang dan memudarnya gairah atau semangat berdoa dan beribadah kepada Allah sepajang hayat. Seseorang disebut sehat secara rohani bila sukacitanya tidak berkurang dan damai sejahteranya tidak hanya karena realita yang dialami yang dihadapi tidak seperti yang diharapkan. Oleh Sinaga menyebut Kesehatan rohani dapat dimaknai sebagai mempunyai konsep diri bahwa ia adalah ciptaan Tuhan sebagaimana yang dituliskan oleh Alkitab. Tuhan menciptakan manusia menurut gambar dan rupa-Nya, karena itu ia perlu menanamkan bahwa Allah mengasihinya, menghargaiya serta mempedulikannya. Apapun keberadaannya di bumi, Allah mengetahui dan sudah memiliki rancangan yang indah. ${ }^{39}$

${ }^{37}$ Danald Capps, Op Cit, 50-55.

${ }^{38}$ Mesach Krisetya, Makalah 1997, h. 5. Masing-masing dikutip dari Henry, C. Link, - The Return to Religion\| dalam Frank G. Gobel, The Third Force: The Psychology of Abraham Maslow, New York: Grossman,1970), h. 124-125.

${ }^{39}$ Triani Devita Sinaga, "Pemulihan Alkitabiah Terhadap Konsep Diri Irasional Kaum Muda," Missio Ecclesiae 7, no. 2 (2018): 259-286. 
Beragam penyebab terjadinya kesehatan rohani jemaat terganggu. Adapun penyebab rohani jemaat terganggu, datang dari faktor permasalahan hidup seperti sakit penyakit. Jemaat dapat terganggu kesehatan rohaninya bila ia sering diperhadapkan dengan derita permasalahan sakit penyakit yang tak kunjung sembuh. Sakit penyakit dapat membawa kerohanian jemaat pudar sehingga menyebabkan sakit secara rohani. Sakit penyakit timbul dapat diakibtkan oleh faktor lingkungan, faktor biologis, faktor psikologis, faktor spiritual, faktor sosial, ekonomi, budaya, pendidikan dan politik, faktor perilaku atau gaya hidup, dan lainya. Simbolon menyebut seseorang bisa sakit karena adanya masalah-masalah yang berhubungan dengan dosa. Terutama dosa yang dipendam, yang tersembunyi bahkan bertahun-tahun lamanya, misalnya dendam yang mengakibatkan pertikaian, perselisihan bahkan peperangan. ${ }^{40}$ Kesehatan rohani jemaat juga dapat terganggu dari permasalahan rumah tangga, dari pekerjaan, perceraian dan sebagainya. Hal-hal ini dapat mengakibatkan jemaat sait rohaninya.

Konselin Kristen berada pada titik tengah, yakni mengarah pada masa kini tapi tidak melupakan pertimbangan dari masa lalu. Dalam dunia konseling terdapat dua ekstrim dalam hal ini yakni pada satu ekstrim, selalu berfokus pada masa lalu dan menjadikannya sebagai 'biang keladi' dari masalah di masa kini. ${ }^{41}$ Pandangan ini berimplikasi pada tidak adanya tuntutan tanggung jawab dari seseorang terhadap perilaku menyimpang atau dosa yang dilakukannya di masa kini. Tokoh yang terkenal dengan kelompok ini adalah Sigmund Freud yang menganggap bahwa masa lampau mempunyai daya takdir, seseorang tidak dapat bebas dari id-nya. Begitu juga menurut psikologi Gestalt, masa lampau tetap hadir pada masa kini sebagai kebiasaan-kebiasaan yang menghambat klien dalam setiap pikiran dan perbuatan. ${ }^{42}$

Di sisi yang lain, menghindari masa lalu atau mengabaikan sama sekali masa lalu dan memandangnya tidak memiliki kaitan yang berarti dengan masa kini. Menurut psikologi eksistensial, masa lampau tidak berarti dan tidak bertujuan, maka tidak perlu dipikirkan. Orang hidup pada masa kini dan di dunia ini. Semua pengaruh berasal dari lingkungan sekarang. ${ }^{43}$ Kedua penekanan di atas, sama-sama tidaklah menawarkan pandangan yang tepat bagi konseling Kristen. Konseling Kristen harus berbalik kembali kepada apa yang dikatakan oleh Alkitab. Alkitab memberikan porsi yang seimbang antara masa lampau dan masa kini. Stanley Heath menyimpulkan pandangan Alkitab tentang kemasalampauan seseorang sebagai berikut: pertama, Pendidikan/pembiasaan yang keliru dan yang harus diperbaiki kembali. Anak manja merupakan contoh. Kedua, Sejarah yang konkret, penuh

\footnotetext{
${ }^{40}$ Sori Tjandrah Simbolon, "Model Pelayanan Pastoral Konseling Terhadap Orang Sakit Berdasarkan Lukas 10: 33-35: Model Pastoral Counseling Services for the Sick Based on Luke 10: 3335," Jurnal Teologi Amreta (ISSN: 2599-3100) 3, no. 2 (2020).

${ }^{41}$ Kawengian, "Tinjauan Teologis Terhadap Emosi Negatif Daud Dalam Mazmur 54:1-14 Dan Implikasinya Bagi Orang Percaya Dalam Situasi Sukar," 187.

${ }^{42}$ W Stanley Heath, Psikologi Yang Sebenarnya (PBMR ANDI, 2021), bk. 76.

${ }^{43}$ Ibid., bk. 77.
} 
dengan peristiwa-peristiwa keberdosaan. Dosa-dosa tersebut membayangi masa kini, misalnya seseorang yang takut bertemu dengan si yang membuatnya trauma. Ketiga, relasi seorang dengan sesamanya sudah rusak sehingga kedua pihak terbayangi rasa dendam dan benci.

\section{KESIMPULAN}

Berdasarkan penjelasan dari uraian di atas, penulis menyimpulkan bahwa pastoral konseling sesungguhnya adalah suatu pelayanan dan pekerjaan yang sangat penting dan mendesak untuk dilakukan oleh seorang gembala, dalam hal ini adalah hamba Tuhan terhadap umat gembalaannya. Pastoral konseling penting untuk dilakukan tentunya karena ada beberapa orang yang merasa terabaikan dalam kehidupannya dan merasa tidak diperdulikan oleh sesamanya. Hal inilah yang seharusnya mendorong seorang gembala untuk memperhatikan domba-dombanya yang sedang membutuhkan pertolongan. Oleh sebab itu, dengan tegas Allah menyatakan bahwa Ia sendiri sebagai gembala yang baik telah dan akan melakukan penggembalaan itu kepada domba-domba-Nya yaitu umat Israel. Allah melalui inisiatif-Nya sendiri akan mencari setiap orang yang hilang, membalut mereka yang terluka, membawa pulang yang tersesat, menguatkan yang sakit, serta melindungi yang kuat dan yang gemuk. Ini menunjukkan bahwa Allah telah melakukan tugas dan tanggung jawabnya sebagai seorang gembala dengan baik. Seorang gembala yang baik tidak mungkin mengabaikan atau tidak memperdulikan pergumulan yang dihadapi oleh umat gembalaannya.

Seorang gembala atau konselor kristen yang baik harusnya lebih mengutamakan fungsinya daripada jabatannya, karena tanpa realisasi nyata dari tugas tanggung jawab yang diembannya seseorang tidak dapat dikatakan sebagai gembala atau konselor yang baik. Seorang gembala yang baik akan selalu memiliki kepekaan yang tinggi akan kebutuhan domba yang dipercayakan kepadanya. Sehingga dengan demikian pelayanan penggembalaan yang dilakukan akan memberikan motivasi dan semangat karena dapat menolong dan mengangkat orang-orang yang sedang membutuhkan pertolongan. Oleh karena itu gembala sebagai konselor dituntut harus memiliki kepekaan terhadap keadaan yang sedang dialami oleh setiap dombadombanya. Karena gembala yang baik pasti mengenal dan mengetahui kebutuhan domba gembalaannya.

\section{REFERENSI}

Aart van Bee. Pendampingan Pastoral. Jakarta: BPK Gunung Mulia, 2007.

Abineno, Johannes Ludwig Chrysostomus. Aku Percaya Kepada Allah. BPK Gunung Mulia, 1983.

Capps, Donald. Biblical Approaches to Pastoral Counseling. Wipf and Stock Publishers, 2003.

Clebsch, William A, and Charles R Jaekle. Pastoral Care in Historical Perspective. Jason Aronson, Incorporated, 1994.

Clinebell, Howard John. Tipe Tipe Dasar Pendampingan |\& Konseling Pastoral. Kanisius, 2002. 
Clinebell, Howard John, and Bridget Clare McKeever. Basic Types of Pastoral Care I\& Counseling: Resources for the Ministry of Healing and Growth. Abingdon Press, 2011.

Cloud, Henry. Changes That Heal: How to Understand Your Past to Ensure a Healthier Future. Zondervan, 1996.

E. P. Gintings. Gembala \& Konseling Pastoral. Yogyakarta: ANDI, 2002.

Harming, Harming. "Metode Penginjilan Yesus Dalam Injil Yohanes 4: 1-42.” Evangelikal 1, no. 2 (2017): 162-169.

Heath, W Stanley. Psikologi Yang Sebenarnya. PBMR ANDI, 2021.

Indra, Ichwei G. "Allah-Manusia Sejati." Semarang: Pelayanan Kristen Mandiri Mikhael, 2000.

Kapojos, Shintia Maria, and Hengki Wijaya. "Perwujudan Kasih Setia Allah Terhadap Kesetiaan Rut." Evangelikal: Jurnal Teologi Injili dan Pembinaan Warga Jemaat 2, no. 2 (2018): 99-104.

Karnawati, Karnawati, Nanda Christiani Ayudea Yahya, and I Putu Ayub Darmawan. "Tahapan Pembelajaran Yesus Pada Perempuan Samaria." Davar: Jurnal Teologi 1, no. 1 (2020): 9-18.

Kawengian, Sherly E.E. "Tinjauan Teologis Terhadap Emosi Negatif Daud Dalam Mazmur 54:1-14 Dan Implikasinya Bagi Orang Percaya Dalam Situasi Sukar." Sekolah Tinggi Teologia Injili Indonesia, 2004.

Lena Anjarsari Sembiring \& Simon Simon. "Rumah Tangga Gembala Sidang Menjadi Role Model Bagi Jemaat.” Teologi Praktika 1, no. 2 (2020).

Loekmono, Lobby, Mesach Krisetya, Kristiana Tjandrarini, A L S Soesilo, Aryatmi Siswohardjono, and Jenny Toisuta. "Saling Menolong Antar Mahasiswa" (1985).

Meier, Paul, Frank Minirth, Frank Wichern, and D Ratcliff. "Pengantar Psikologi Dan Konseling Kristen." Yogyakarta: PBMR ANDI (2004).

Nainupu, Marthen. "Konseling Pastoral Dalam Gereja: RES SINE QUA NON." JTA 20, no. 11 (2009): 78-100.

Oates, Wayne E. Pastoral Counseling. Westminster John Knox Press, 1981.

Pattinama, Yenny Anita. "Pastoral Konseling Menurut Yehezkiel 34: 16 Sebagai Upaya Pemulihan Mental." SCRIPTA: Jurnal Teologi dan Pelayanan Kontekstual 6, no. 2 (2018): 172-183.

Simbolon, Sori Tjandrah. "Model Pelayanan Pastoral Konseling Terhadap Orang Sakit Berdasarkan Lukas 10: 33-35: Model Pastoral Counseling Services for the Sick Based on Luke 10: 33-35." Jurnal Teologi Amreta (ISSN: 2599-3100) 3, no. 2 (2020).

Simon, Simon. "Peranan Gereja Dalam Menghambat Laju Pertumbuhan Pemakai Narkoba." Jurnal Ilmiah Religiosity Entity Humanity (JIREH) 1, no. 2 (2019): 172-186.

Simon, Simon, and Alvonce Poluan. "Model Kepemimpinan Yang Ideal Dalam Penataan Organisasi Gereja." SHAMAYIM: Jurnal Teologi dan Pendidikan Kristiani 1, no. 2 (2021): 133-147.

Sinaga, Triani Devita. "Pemulihan Alkitabiah Terhadap Konsep Diri Irasional Kaum Muda." Missio Ecclesiae 7, no. 2 (2018): 259-286.

Situmorang, Jonar T H. Soteriologi: Doktrin Keselamatan, Pengajaran Mengenai Karya Allah Dalam Keselamatan. PBMR ANDI, 2021.

Storm, M Bons. "Apakah Penggembalaan Itu." Jakarta: BPK Gunung Mulia (1988). 
Subagyo, Joko. “Metode Penelitian Dan Praktek." Jakarta: Rhineka Cipta (1991). Tjaard Band \& Anne Hommes. Konseling Krisis. Yogyakarta: Pusat Pastoral, 2000. Van, Niftrik G C, and B J Boland. “Dogmatika Masa Kini." Jakarta: BPK. Gunung Mulia (2015).

Waharman, Waharman. "Prinsip Penggembalaan Dalam Mazmur 23." Manna Rafflesia 1, no. 2 (2015): 93-111.

Widiyanto, Mikha Agus, and S Susanto. "Pengaruh Pelayanan Kunjungan Pastoral Terhadap Pertumbuhan Rohani Jemaat.” Evangelikal: Jurnal Teologi Injili Dan Pembinaan Warga Jemaat 4, no. 1 (2020): 39-46.

Yancey Philip. Kitab Suci Yang Dibaca Yesus. Batam: Interaksara, 2001. 